\title{
Traumatic Stressful Life Events and Coping Ways of Female Workers of the Kabul University Female Dormitory
}

\author{
Spozhmay Oriya \\ Faculty of Psychology, Kabul University, Kabul, Afghanistan
}

\section{Email address:}

oriyakhel@yahoo.com

\section{To cite this article:}

Spozhmay Oriya. Traumatic Stressful Life Events and Coping Ways of Female Workers of the Kabul University Female Dormitory. Psychology and Behavioral Sciences. Vol. 8, No. 4, 2019, pp. 85-90. doi: 10.11648/j.pbs.20190804.11

Received: July 7, 2019; Accepted: August 13, 2019; Published: August 23, 2019

\begin{abstract}
This qualitative study investigated the traumatic and stressful life events of female workers at the female dormitory of Kabul University. Qualitative method was used for this study, and data were collected through focus groups and in-depth interviews. A total of 24 female workers of Kabul University at female dormitory participated in this study. The overall result shows that majority of workers have experienced several traumatic and stressful life events in their personal life and in the work environment. These experiences included painful memories of war, loss and death of family members and friends, family violence, economic problems, accidents in work environment and etc. This study found that in spite of problems on their lives, the participants used some meaningful ways for coping with problems, which showed their resilience toward problems. According to the results of this study, we can say that the daily life of female workers at the female dormitory of Kabul University impacted by traumatic and stressful events, and this could create psychological and physical problems in long-term for them and affect their functioning in personal and professional life. The findings for this study could be used to address the problems of these workers.
\end{abstract}

Keywords: Traumatic Life Events, Coping, Female Workers, Kabul University, Afghanistan

\section{Introduction}

Afghanistan is a country with more than three decades of war and insecurity. Mental health problems, violence, loss and trauma, economic problems and poverty, and unemployment are the consequences of these decades of war. Every afghan are suffering from the consequences of war. Afghan people for decades experienced armed conflict, displacement and psychological trauma and several researches reports the high levels of depression and anxiety among general population [1]. According to the survey of Afghan ministry of public health which was conducted with support of European Union, one in two afghan suffer from psychological stress. This survey revealed that fifth of the population have problem in doing routine tasks [2]. Some studies showed that level of prevalence of some mental disorders such as depression, anxiety and psychological distress are high in women than men. Several social, cultural, financial, and environmental risk factors affects women's mental health $[3,4]$. Psychological problems are more common among women and those who experienced multiple traumas [5].

Researchers define traumatic and stressful events as those events which cause distress and adjustment issues. Traumatic life events are distinct experiences that include death or threat to that, serious injury, or physical threat to one-self or others. These events include death of loved ones, physical or sexual assaults, life-threatening accidents, serious medical diseases, sudden loss of shelter, or sudden loss of job $[6,7]$. The traumatic life events are discrete experiences which disturb the normal activities and routine of individuals, and causing fundamental change and readjustment. People who are exposed to traumatic events, may experience a wide range of psychological distress symptoms that include unwanted memories about those events, behavioural and emotional avoidance, hyper arousal (alertness), sadness, anxiety, and feeling of guilt $[8,9]$.

Traumatic stress occurs as a result of being faced to death, helplessness, and total loss of control. These events differ in their severity, duration and the meaning which it have for individuals. Some events such as death of a family member have greater impact and results in great change [10]. 
Traumatic events not only cause mental health problems but also increase physical problems like headache, stomach-ache, back pain, and so on [11]. The ways an individual copes with traumatic life events, are the important anticipators of how well an individual adjust with that [12].

Coping is the "process of managing in difficult circumstances, which include developing strategies to deal with both internal and external stress and to expend efforts in the most useful ways, while postponing some tasks in order to accomplish the most pressing first' [13]. Carolyn Aldwin (1993) stated that Lazarus and Folk man (1984) define coping as behaviour and cognition, which is used by individuals in managing stressful situations and negative threatening emotions [14]. The main sources of coping with life problems and stress include physical sources (health and action), psychological sources (personality treats, values, goals, religious beliefs, self-concept, and self-control), and social sources (social network and social support). Out of all, social support has the more effective role in dealing with stressful life events [9].

In Afghanistan, no specific research has been conducted on traumatic events experienced by female workers. But the results of surveys on women's problems in general indicate high psychological problems such as depression, anxiety and trauma among them. These studies also show that some Afghan women, in spite of war experiences and daily life problems, have shown significant resilience toward their problems [15]. Some surveys on women workers found some stressful events in their work environment. A survey, which was done on 150 women workers in Balkh province, shows that insufficient income and high burden of work are the main factors of workers' distress. Furthermore, this survey indicated that 41 per cent of workers spend all of their income on their families [16]. The results of another survey, which was done in Herat province on women workers, show that lack of health services in work environment and tremendous amount of work were the main problem of female workers [17].

Likewise, researches on female workers in other countries also found that women workers experience a heavy burden of work on their family and work environment. A qualitative research on worker women in Agni collage of technology in India found that, because of additional responsibilities in work environment and family, most of the female workers were under pressure [18]. Moreover, another qualitative research on 23 female workers in Hong Kong found that some workers showed their resiliency by rationalizing their role, believing in their abilities for making change in life and being optimistic. This study found that workers used ways such as accepting their limits and responsibilities for coping with stressful life events [19].

Female workers in Kabul University Female Dormitory also have heavy responsibility of addressing family and work environment affairs. They are expected to perform their tasks properly, and the hypotheses are that when they experience traumatic and stressful events, they become more stressed and their relationship gets affected negatively. Hence, this study is designed to find out about the types of traumatic and stressful events experienced by female workers of the Kabul university female dormitory, and their coping ways with these problems.

The aims of research were as follows:

a) To identify the traumatic and stressful life events in women workers of the Kabul university female dormitory.

b) To identify the stressful events in the work environment of women workers of the Kabul university female dormitory.

c) To identify the coping strategies used by women workers in dealing with psychological stress.

\section{Methods}

This study conducted on female workers of Kabul University female dormitory in January 2016. Through purposeful sampling method, also called non-probability sampling, 24 women workers were selected in this study. In purposeful sampling, easily accessible and interested people were selected. This method is commonly used in qualitative research [20, 21]. The participants were aged between 32 to 65 years old and majority of them were uneducated; only some of them had participated in the literacy courses and were able to read and write. All participants were married, and some were widows.

Focus group discussion and in-depth interviews were used as tools of data collection. Two focus group discussions and two in-depth interviews were conducted. Focus group is an ideal method for studying people's stories, ideas, and experiences, beliefs, needs, and concerns. In-depth interview is another technique of qualitative research, which collects data from fewer numbers of respondents through focused interviews to explore their viewpoints about a specific idea, program or situation [22]. The interviews were recorded and transcribed and the date were analysed by coding them and subsequently categories were created. The categories are discussed under the findings.

\section{Findings}

\subsection{Traumatic and Stressful Events in Workers Personal Life}

The findings of this study show that majority of the participants experienced lots of problems and traumatic stressful events in their personal lives. Most of the respondents reported that they personally experienced, witnessed or heard from others about the events like loss of their loved ones, fire, explosions, accidents in their home and workplace. Other traumatic events and life problems were resulted from, insecurity, poor economic status, low income, or the existence of illnesses in the family. These workers stated that as a result of painful experience in life, they experienced severe psychological distress and physical pains, these women used Dari terms such as Jigar khon for being 
depressed and grief related to their painful experiences in life and Asabani for their anger and being nervous from their stressful experiences. Most of these women had bad experiences of civil war in the country and lost their loved ones. The 65 year old women said about her traumatic experiences during the civil war in the country. She said that how her 14 years old daughter became victim of war and she lost her by shoot of a bullet hitting her head. This woman said that "always I see the bloody body of my daughter in my dreams and till now after 12 years I remember her and cry. She was in my arms and blood was pouring from her hairs. Now any suicide attack and expulsion remind me my daughter and I do not eat for a week because I think I eat the blood". This woman wept a lot during the interview.

Another woman in the in-depth interview talked about her child marriage and the domestic violence that she experienced. She said that how she experienced hard days with her husband who was member of Taliban group, already married and addicted, how she worked on land of poppy, and how she experienced her husband's violent behavior. She says "my husband which was very older than me, always badly beat me and even one day he cut my leg with knife and said that if you tell to anyone I will kill you. But I tolerated because of my father and family's honor, my children and I hoped that one day this violence will be ended".

The participants suffered from physical pains in different parts of their body and in some cases their problems affected their relationships with themselves and with their family members and colleagues. For example, they stated that they are beating their children and shouting on their family members and colleagues and then fell regret and wept. Experiencing work stress by female workers is another important finding of this study.

\subsection{Experienced Work Stress}

Majority of the respondents reported that besides experiencing psychological distress from traumatic events in their personal life, they also experience work stress. According to the respondents, less number of workers in proportion of students in the dormitory is an important stressor for them because in this case the load of work for them is increasing. Long work hours and less income were another important stressor. The workers reported that they work more extra hours, and even on holidays they have to stay in the dormitory, and they receive less extra income compared with the services they offer.

Another important issue that the workers pointed out is the occurrence of some events or accidents in their workplace, which have caused them physical injuries and psychological distress. Some workers mentioned that they have experienced severe accidents in their work environment like burning of their hands or legs as a result of boiled water and hot oil, cutting of fingers in meat grinder, falling from stairs during work, experiencing electric shock during work and etc. During the focus group one participant which lost her one finger in meat grinder machine said that "even now that I am talking about that day which I lost my finger I feel bad and feel the pain of that day and the painful memory is after that I paid the expenses of my treatment myself" Lack of health insurance found to be another source of stress for workers. Participants stated that they do not have health insurance and when they face health-related problems, they have to bear the expenses on their own, and because of this reason sometimes, they lose their motive for working in such an environment.

As per findings from this study, inappropriate behaviour of some students with workers, students' sickness, fighting and clashes between students also put them under stress and a lot of pressure. Furthermore, workers were annoyed from unfamiliarity and incaution of some students, especially new comers, with dorm environment and equipment. They stated that many students, new comers, in particular, are not familiar with proper ways of using the dorm's facilities, and pay less attention to keep clean their rooms and dorm's environment.

These findings were supported by the experiences of the dorm's teachers, who had the same ideas in this regard. Even they confirmed the existence of ethnic and religious bias among students which sometimes lead to clashes and even physical violence among them. They mentioned that such behaviour negatively impact the well-being of not only workers but also all the administrative staff and students.

\subsection{Coping Strategies}

Despite problems that exist within the personal life of workers, there are some factors that encourage them to work and help them to cope with problems and forget their pains temporarily. Some of those factors are mentioned below.

All of participants of this study showed happiness because of having a job which helps them to support their family and decrease their financial problems, and also they felt themselves physically and psychologically safe and secure, because they work in the dormitory where the majority of workers are female, so they feel a level of comfort there. They said "we are all women here and have same experiences and when we share our problems we feel that we are not alone and because of same experiences we understand each other easily".

Strong religious beliefs and practices found to be an important way of coping with traumatic stressful life events for female workers. According to participants believing in Almighty Allah, praying, and going to shrines help them deal with life distress. The participants stated that besides religious beliefs, they also use other ways such as, thinking about their children's future and family honour, spending time with children and family members, talking to reliable friends and colleagues, leaving places and things that causing them distress, to cope with their problems.

Some of the workers stated that they find their mental comfort in blaming others, quarrelling with others or distancing themselves from others, and not talking to others. According to them, these methods are helping them to feel better and behave normally after some times. Overall, main problems of female workers in Kabul University female dormitory could be categorised into economic problems, work-related problems, 
personal and family problems. Details are in the following table:

Table 1. Summary of focus groups and in-depth interviews.

\begin{tabular}{|c|c|c|c|c|}
\hline Economic problems & War \& insecurity & Personal \& family problems & Work environment problems & Coping ways \\
\hline 1. Poverty & 1. Insecurity in the country & 1. Violence in the family & 1. Too much load of work & $\begin{array}{l}\text { 1. Believe in almighty } \\
\text { Allah and praying }\end{array}$ \\
\hline 2. Less income & $\begin{array}{l}\text { 2. Being witness of violent } \\
\text { events during war }\end{array}$ & 2. Forced marriage & $\begin{array}{l}\text { 2. Less number of workers in } \\
\text { comparison to students number }\end{array}$ & $\begin{array}{l}\text { 2. Resistance and } \\
\text { tolerance in front of } \\
\text { problems }\end{array}$ \\
\hline $\begin{array}{l}\text { 3. Decrease of part-time } \\
\text { salary in comparison to } \\
\text { past years }\end{array}$ & $\begin{array}{l}\text { 3. Losing of family } \\
\text { member in war }\end{array}$ & 3. being illiterate & $\begin{array}{l}\text { 3. Lack of some students } \\
\text { cooperation in keeping clean } \\
\text { the dormitory }\end{array}$ & 3. taking rest \\
\hline \multirow[t]{10}{*}{$\begin{array}{l}\text { 4. Unemployment of } \\
\text { husband }\end{array}$} & $\begin{array}{l}\text { 4. feeling bad because of } \\
\text { watching violent } \\
\text { commercial on } \mathrm{TV}\end{array}$ & $\begin{array}{l}\text { 4. having sick member in the } \\
\text { family }\end{array}$ & $\begin{array}{l}\text { 4. Feeling unprotected toward } \\
\text { work accident }\end{array}$ & $\begin{array}{l}\text { 4. Sharing problems with } \\
\text { colleagues and family } \\
\text { members }\end{array}$ \\
\hline & & 5. Pressure being household & 5. Lack of health insurance & $\begin{array}{l}\text { 5. Believe in their } \\
\text { abilities in facing } \\
\text { problem }\end{array}$ \\
\hline & & 6. Personal sickness & $\begin{array}{l}\text { 6. Clashes and conflicts among } \\
\text { students }\end{array}$ & $\begin{array}{l}\text { 6. Having job and } \\
\text { income }\end{array}$ \\
\hline & & 7. Husband's death & $\begin{array}{l}\text { 7. Improper behaviour of some } \\
\text { students with workers }\end{array}$ & 7. Having children \\
\hline & & 8. Husband's unemployment & & $\begin{array}{l}\text { 8. Leaving stressful } \\
\text { environment }\end{array}$ \\
\hline & & $\begin{array}{l}\text { 9. Problem in looking after of } \\
\text { the family alone }\end{array}$ & & $\begin{array}{l}\text { 9. Feeling good for } \\
\text { helping others }\end{array}$ \\
\hline & & 10. Physical pains & & $\begin{array}{l}\text { 10. Thinking about } \\
\text { honour of the family }\end{array}$ \\
\hline & & 11. Psychological distress & & $\begin{array}{l}\text { 11. Being hopeful for } \\
\text { better future }\end{array}$ \\
\hline & & 12. addicted husband & & $\begin{array}{l}\text { 12. blaming others and } \\
\text { quarrelling }\end{array}$ \\
\hline & & $\begin{array}{l}\text { 13. being widow } \\
14 \text {. worry about son's migration }\end{array}$ & & \\
\hline
\end{tabular}

\section{Discussion}

The findings from this study show that majority of the participants have experienced or witnessed or heard about some sorts of traumatic events related to the war. The main cause is that more than three decades of war has overwhelmed these women and made them distressed and keep struggle in life. Their traumatic and stressful experiences in their personal life and work environment are related to each other. This study found that low income, heavy workload and lack of health services are the main sources of female worker's distress in the work environment which create stress. These findings are similar to the findings from two surveys, which were conducted on female workers in Balkh and Herat Provinces of Afghanistan in 2014 and 2015. Those surveys also found that lack of healthcare services; heavy workload and low income are main sources of distress. These findings clearly indicate that female workers experience a lot of pressure in their work environment, and no or little attention has been paid to protect their rights. One thing that differentiates this study from other studies on afghan workers is the war related stress and traumatic experiences which interact with work environment stress.

Furthermore, the findings from this study are similar to Bhuvaneshwari (2013) findings on female workers in India. Both studies indicated that because of family and work responsibilities, the participants were under stress. The reason for similarity in both findings could be the similar responsibilities of women in family environment. Moreover, the findings of this study are in line with some findings from a study which was done on female workers in Hong Kong [14]. Both studies found that participants believed on their abilities and were optimistic; therefore, they had shown resiliency against problems. The findings from this study support the findings from a study done by Omidian \& Miller (2006) on Afghan women. Their research findings show that Afghan women are experiencing high levels of psychological distress and trauma, but despite war experiences and daily life problems, they have high resilience, which helped them cope with life problems and stressors. The results from both studies indicated that despite traumatic experiences, Afghan women are optimist toward life and different things such as praying, thinking about family members and children, and having a job that helped them to tolerate psychological distress and increase in their resiliency. As stated earlier, Afghan female workers have high resilience because in spite of experiencing traumatic events and stressful situations they keep on struggling to live, using their resources to come out of traumatic events and crisis in their lives and not give up. So they use different ways like talking to friends and coworkers, praying, to cope with traumatic events. These findings are in line with the existed literature on coping methods with traumatic events. The literature shows that individual's religious beliefs and social support have the 
substantial role in dealing with traumatic events [5]. The reason of this harmony in both studies is that, human beings have some similar characteristics, which could create meaning in their life and help them cope with stress of life events and problems.

\section{Conclusion and Suggestions}

As per findings from this study, female workers of Kabul University's female dormitory have experienced several traumatic stressful life events. Such as death of husband, loss of their sons, children and loved ones in war or because of illness, having ill family member, tolerance of heavy load of family expenses, look after of children alone without husband, and many other traumatic and stressful events. Also all of the participants had experienced lots of stress such as heavy burden of work, accidents, low salary, and most important, don't having work and life insurance in their work environment. This study shows that war is not the only trauma more ever experiences of war and daily stressors together can cause more stress.

Problems and distresses based on traumatic stressful life events, which is the result of war and insecurity in the country create stress, these war stresses together with work environment problems negatively impact physical, psychological and social function of female workers at their homes and work environment, and decrease their output. and it cause that some of them could not use proper coping methods in dealing with problems such as some participants has used negative coping ways like blaming others and quarreling. Women workers' problems in Kabul University's female dormitory could be an indicator of problems faced by people in stressful environments. Furthermore, it could be the indicator of war stress in worker's class problems in the entire country.

Suggestions that made by female workers for improvement of dormitory environment:

a) Holding more introduction programs for new comers in dorm in order to increase or enhance their information about dorm rules and regulations.

b) Providing health insurance to workers to make them feel protected

c) Increase their monthly income and pay for extra work they do for dormitory according to their work load.

d) Paying attention to recruitment of more workers in dormitories.

Suggestions for addressing the female workers' problems and improving their wellbeing:

a) Establish of counseling room inside the dorm or counseling center in Kabul University with help of ministry of higher education.

b) Conducting stress management and anger management programs for dormitory workers from side of faculty of psychology and other related associations.

c) Conducting coping methods trainings for dorm's workers and teachers.

d) Attention to living conditions of dorm's workers from side of ministry of higher education.

Suggestion for future research:

e) Conducting research on trauma and post traumatic stress on female workers of dormitory.

f) Conducting research on psychological wellbeing of female workers of dormitory.

\section{References}

[1] Vogel, M., Tschakarjan, S., Maguet, O., Vandecasteela, O., Kinkel, T., \& MacFarland, K. D. (2012). Mental Health among opiate users in Kabul: a pilot study from the Medecins du Monde Harm Reduction Program. Intervention, 10 (2), 146-155.

[2] Survey indicates that Half of Afghan Population is Under Psychological Stress. (2018, Oct 28). Retrieved from http://reporterly.net/latest-stories/survey-indicates-that-half-ofafghan-population-is-under-psychologicalstress/?fbclid=IwAR1ixrEh-xwQ8jNRQb0nVDI0Y32KW9mz1oO-DmYboJRaHdvr-11t0BQ_Ok.

[3] WHO. (2000). Womens mental health: an evidence based review. Department of mental health and substance dependence. Geneva: World Health Organization, 6-12.

[4] Mokhtari, M., Dehghan, S. F., Asghari, M., Ghasembaklo, U., Mohamadyari, G., Azadmanesh, S., et al. (2013). Epidemiology of mental health problems in female students: A questionaire survey. Journal of Epidemiology and global health, 83-88.

[5] Scholte, w., Olff, M., Ventevogel, P., Vries, G.-J., Jansveld, E., Cardozo, B. L., \& Crowford, C. G. (2004). Mental Health Symptoms Following War and Repression in Eastern Afghanistan. Journal of American Medical Association, 292 (5), 585-593.

[6] Gray, M., Litz, B., Hsu, J., \& Lombardo, T. (December/2004). psychometric Properties of the Life Events Checklist. Assessmebt, 11 (4), 330-341.

[7] Grayman-Simpson, N., Mattis, j., \& Tomi, N. (2016). Africana women's ways of Coping with Traumatic Life Events: A Meta-Ethnography. USA. 25-45.

[8] Australiana Center for Postraumatic Mental health.(2012) . Literature Review: The Nature of the Relationship between Traumatic Events in People's Lives and Homelessness. Melbourne: Austraian Center for Posttraumatic Mental Health. $1-44$.

[9] Jang, Y., \& Haley, W. (2002). Life event and stress. Retrieved from encyclopedia.com: http://www.encyclopedia.com/doc/1G2-3402200230.html.

[10] Compas, B. (1987). Stress and Life Events During Childhood and Adolescence. Clinical Psychology Review. Pergamon Journal, 275-302, vol (7).

[11] Schwarzer, R., \& Schulz, U. (2001). The Role of Stressful Life Events. Germany, 1-32.

[12] Updegraff, J \& ,.Taylor, S .(2000) .From Vulnerability to Growth: Positive and Negative Effects of stressful Life Events. In J. Harvey\&E. Meller (Eds). Loss and Trauma: General and Close Relationship Perspectives. 3-28. Philadelphia, PA: Brunner-Routledge. 
[13] Matsumoto, David. 2009. The Cambridge Dictionary of Psychology. New York, Cambridge University Press, p, 524.

[14] Aldwin, C. (1993). Coping with Traumatic Stress. PTSD Research Quarterlyp, 4 (3), pp. 1-8.

[15] Omidian, $\mathrm{P}$ \& ,.Miller, $\mathrm{K}$.(2006) .Addressing the Psychosocial Needs of Women in Afghanistan .Critical Half. $17-21$.

[16] Ekrami, Sadia. 14/11/2014. the condition of worker women (radio report). Retrived from http://www.aihrc.org.af/home/daily_report/3879.

[17] People radio. 2015. wory of increaseing of women workers problems in Herat. Herat Afghanistan.

[18] Bhuvaneshwari, M. (2013). A Case Study on Psychological and Physical Stress Undergone by Married Working Women. Journal of Business and Management, 14 (6), 38-44.
[19] Yuen, W. W.-Y., wong, w. C.-w \& ,.Tang, C. S.-K.(n. d). Resilience in Work-Related Stress among Female Sex Workers in Hong Kong. From http://qhr.sagepub.com/content/24/9/1232.Abstract.

[20] Teddlie, C. Y .(2007) .Mixed Methods Sampling: A Typology with Examples .Journal of Mixed Methods Research, 77-100, (1) 1, Sage Publication.

[21] Hardon, A., Hodgkin, C., \& Fresle, D. (2004). How to Investigate the use of medicines by consumers. WHO, Applied Health Research: Anthropology of Health and Health Care. 1-89.

[22] Boyce, C., \& Neale, P. (2006). Conducting In-Depth Interviews: A Guide for Designing and Conducting In-Depth Interviews for Evaluation Input. Pathfinder International Tool Series. 1-12. 